\title{
Pemanfaatan Energi Matahari sebagai Sumber Energi Alternatif Pada Proses Produksi Hidrogen pada Hidrofill
}

\author{
Choirul Saleh ${ }^{1}$, Rachmadi Setiawan ${ }^{2}$, Bima Romadhon Parada D P*3 \\ 1,2,3 Jurusan Teknik Elektro, Institut Teknologi Nasional, Malang \\ choirulsaleh@lecturer.itn.ac.id ${ }^{1}$, rachmadi@lecturer.itn.ac.id ${ }^{2}$, bimarpdp@lecturer.itn.ac.id ${ }^{3}$
}

\begin{abstract}
Abstrak
Ketergantungan terhadap bahan bakar fosil, memiliki tiga ancaman serius, yaitu kenaikan harga akibat permintaan yang besar, menipisnya cadangan minyak, serta polusi gas rumah kaca $\left(\mathrm{CO}_{2}\right)$. Isu lingkungan global yang menuntut tingkat kualitas udara yang baik, mendorong berbagai pakar energi untuk mengembangkan energi yang ramah lingkungan. Hidrogen merupakan bahan bakar yang banyak mendapatkan perhatian untuk dikembangkan, karena merupakan bahan bakar yang ramah lingkungan dan berpotensi menggantikan bahan bakar fosil. Produksi hidogen dapat dilakukan dengan melakukan proses elektrolisis air. Meskipun elektrolisis air telah dikenal selama sekitar 200 tahun itu masih menyumbang 4\% hidrogen yang dihasilkan oleh elektrolisis karena efisiensi proses produksi yang rendah. Produksi gas yang rendah dan konsumsi energi yang tinggi adalah masalah serius elektrolisis air. Rata-rata 4,5-5,0 $\mathrm{kWh} / \mathrm{m}^{3} \mathrm{H}_{2}$. Teknologi elektrolisis yang memanfaatkan matahari sebagai sumber energi merupakan teknologi produksi hidrogen yang ramah lingkungan yang didapatkan secara gratis dari alam. Akan tetapi energi listrik yang dihasilkan sel surya sangat dipengaruhi oleh intensitas cahaya matahari, sehingga daya yang dihasilkan oleh panel surya bersifat fluktuatif. Ada banyak sistem kontrol yang telah dikembangkan untuk mengendalikan tegangan keluaran panel surya agar lebih stabil, salah satunya Buck converter dengan metode kompensator PID. Mengenai metode PID, sistem kontrol ini memiliki respon cepat, tidak ada offset, tidak ada osilasi, dan dapat digunakan dengan proses orde tinggi dibandingkan kontrol PI dan PD. Dari pengujian yang telah dilakukan terlihat bahwa konsumsi energi listrik pada produksi Hidrogen menggunakan elektrolisis air, menggunakan kendali PID memiliki efisiensi kinerja yag lebih baik, dengan rata-rata konsumsi daya sebesar 5400 Watt Hour atau sekitar 96,5\% konsumsi energi yang digunakan oleh sistem tanpa kendali PID yang mencapai 5594 Watt Hour.
\end{abstract}

Kata Kunci : Elektrolisis, Hidrogen, Panel Surya, PID, Termokimia

\begin{abstract}
Dependence on fossil fuels poses three serious threats, such as price increases due to large demand, depletion of oil reserves, and pollution of greenhouse gases (CO2). Global environmental issues that demand a good level of air quality have encouraged various energy experts to develop environmentally friendly energy. Hydrogen is a fuel that is getting a lot of attention to be developed, because it is an environmentally friendly fuel and has the potential to replace fossil fuels. Hydogen production can be done by electrolyzing water. Although water electrolysis has been known for about 200 years it still accounts for $4 \%$ of the hydrogen produced by electrolysis due to the low efficiency of the production process. Low gas production and high energy consumption are serious problems of water electrolysis. Average 4.5-5.0 $\mathrm{kWh} / \mathrm{m} 3 \mathrm{H} 2$. Electrolysis technology that utilizes the sun as an energy source is an environmentally friendly hydrogen production technology that is obtained free of charge from nature. However, the electrical energy produced by solar cells is strongly influenced by the intensity of sunlight, so that the power generated by solar panels is fluctuating. There are many control systems that have been developed to control the output voltage of the solar panel to make it more stable, one of which is the Buck converter with the PID compensator method. Regarding the PID method, this control system has fast response, no offset, no oscillation, and can be used with higher order processes than PI and PD controls. From the tests that have been done, it can be seen that the consumption of electrical energy in Hydrogen production using water electrolysis, using PID control has a better performance efficiency, with an average power consumption of 5400 Watt Hours or about $96.5 \%$ of the energy consumption used by the system without PID control that reaches 5594 Watt Hour.
\end{abstract}

Keywords : Electrolysis, Hydrogen, PID, PV, Thermochemical 


\section{PENDAHULUAN}

Saat ini kebutuhan energi di Indonesia sebagian besar masih didominasi oleh penggunaan bahan bakar fosil. Ketergantungan terhadap bahan bakar fosil, memiliki tiga ancaman serius, yaitu : kenaikan harga akibat permintaan yang besar, menipisnya cadangan minyak, serta polusi gas rumah kaca $\left(\mathrm{CO}_{2}\right)[1]$. Isu lingkungan global yang menuntut tingkat kualitas udara yang baik, mendorong berbagai pakar energi untuk mengembangkan energi yang ramah lingkungan. Hidrogen merupakan bahan bakar yang banyak mendapatkan perhatian untuk dikembangkan, karena merupakan bahan bakar yang ramah lingkungan dan berpotensi menggantikan bahan bakar fosil. Permasalahan utama dari produksi hidrogen, sampai saat ini masih diproduksi dari bahan bakar fosil misalnya, gas alam atau bahan bakar fosil lainnya[2], seperti steam reforming dan termokimia siklus sulfur-iodine. Steam reforming dari metana merupakan teknologi yang sudah teruji dan sudah banyak digunakan. Sedangkan siklus sulfur-iodine merupakan proses termokimia yang sedang dalam tahap pengembangan[3].

Selain dua metode sebelumnya, alternatif produksi hidogen dapat dilakukan dengan melakukan proses elektrolisis air[4]. Meskipun elektrolisis air telah dikenal selama sekitar 200 tahun itu masih menyumbang hanya sebagian kecil dari total produksi hydrogen[2]. Hanya 4\% hidrogen yang dihasilkan oleh elektrolisis karena efisiensi proses produksi yang rendah. Produksi gas yang rendah dan konsumsi energi yang tinggi adalah masalah serius elektrolisis air. Rata-rata 4,5-5,0 kWh / $\mathrm{m}^{3} \mathrm{H}_{2}$ [5].

Penelitian terdahulu yang membahas tema yang sama dilakukan oleh Suryanto, penelitian ini dilakukan proses elektrolisis dengan variasi tegangan dan variasi kadar salinitas. Elektrolit yang digunakan adalah $\mathrm{NaCl}$ (Natrium Chlorida) dengan variasi tegangan $(2,1 \mathrm{~V} ; 6 \mathrm{~V} ; 12 \mathrm{~V})$ dan variasi kadar salinitas $(0,5 \%, 15 \%, 35 \%)$. Elektroda yang digunakan adalah platina sebagai anoda dan stainless steel sebagai katoda akan dialiri arus bermuatan positif pada anoda dan bermuatan negatif pada katoda[6]. Tetapi hasil penelitian yang dilakukan Suryanto masih belum menjanjikan dalam hal efisiensi produksi.

Teknologi elektrolisis yang memanfaatkan matahari sebagai sumber energi merupakan teknologi produksi hidrogen yang ramah lingkungan yang didapatkan secara gratis dari alam[7]. Di Indonesia yang merupakan daerah tropis mempunyai potensi energi matahari sangat besar dengan insolasi harian rata-rata $4,5-4,8 \mathrm{KWh} / \mathrm{m}^{2} /$ hari. Akan tetapi energi listrik yang dihasilkan sel surya sangat dipengaruhi oleh intensitas cahaya matahari, sehingga daya yang dihasilkan oleh panel surya bersifat fluktuatif[8].

Ada banyak sistem kontrol yang telah dikembangkan untuk mengendalikan tegangan keluaran panel surya agar lebih stabil, salah satunya Buck converter. Buck Converter sendiri memiliki kekurangan dalam pengendalian tegangan keluaran dari panel surya karena energi yang dihasilkan bersifat fluktuatif, sehingga diperlukan sebuah metode kompensator PID. Penelitian yang dilakukan oleh Pane, J., Novita, S., Aryza, S., Hamdani, H., Rizky, R., \& Ahmad mengenai metode PID menyimpulkan sistem kontrol ini memiliki respon cepat, tidak ada offset, tidak ada osilasi, dan dapat digunakan dengan proses orde tinggi dibandingkan kontrol PI dan PD[9][10].

\subsection{Elektro Kimia}

\section{METODOLOGI}

Suatu metode yang digunakan untuk menghasilkan listrik dari reaksi redoks spontan atau sebaliknya. Dalam setiap proses elektrokimia, elektron mengalir dari satu zat kimia ke zat lainnya, digerakkan oleh reaksi oksidasi-reduksi (redoks). Reaksi redoks terjadi ketika elektron ditransfer dari zat yang teroksidasi menjadi zat yang sedang direduksi. Reduktor adalah zat yang kehilangan elektron dan teroksidasi dalam proses tersebut, oksidan adalah zat yang memperoleh elektron dan berkurang dalam proses. Energi potensial yang terkait ditentukan oleh perbedaan potensial antara elektron valensi dalam atom unsur yang berbeda. Karena tidak mungkin untuk memiliki reduksi tanpa oksidasi dan sebaliknya, reaksi redoks dapat digambarkan sebagai dua reaksi setengah, satu merupakan proses oksidasi dan satu proses reduksi. Untuk reaksi Seng dengan Bromin, keseluruhan reaksi kimia adalah sebagai berikut:

$$
\mathrm{Zn}_{(\mathrm{s})}+\mathrm{Br}_{2(\mathrm{aq})} \quad \rightarrow \quad \mathrm{Zn}_{(\mathrm{aq})}{ }^{2+}+2 \mathrm{Br}_{(\mathrm{aq})}{ }^{-}
$$

Setengah reaksi adalah sebagai berikut:

$\mathrm{Br}_{2(\mathrm{aq})}+2 \mathrm{e}^{-} \quad \rightarrow \quad 2 \mathrm{Br}_{(\mathrm{aq})}^{-}$ 


$$
\mathrm{Zn}_{(\mathrm{s})} \quad \rightarrow \quad \mathrm{Zn}_{(\mathrm{aq})}{ }^{2+}+2 \mathrm{e}^{-}
$$

Setiap setengah reaksi ditulis untuk menunjukkan apa yang sebenarnya terjadi dalam sistem, $\mathrm{Zn}$ adalah reduktor dalam reaksi ini (kehilangan elektron), dan $\mathrm{Br}_{2}$ adalah oksidan (memperoleh elektron). Menambahkan dua setengah reaksi memberikan reaksi kimia keseluruhan (Persamaan 1). Reaksi redoks seimbang ketika jumlah elektron yang hilang oleh reduktor sama dengan jumlah elektron yang diperoleh oksidan. Seperti halnya persamaan kimia seimbang, keseluruhan proses ini netral secara listrik, artinya, muatan netto sama di kedua sisi persamaan[11].

\subsection{Elektrolisis}

Dalam sel elektrolisis air, listrik digunakan untuk memecah molekul air menjadi hidrogen dan oksigen gas. Reaksi setengah sel (dan mekanisme yang terkait) bergantung pada $\mathrm{pH}$ elektrolit. Dalam media asam, pemisahan air terjadi menurut (Persamaan 4,5,6). Produksi gas oksigen dan hidrogen dapat dilakukan melalui proses elektrolisasi air $\left(\mathrm{H}_{2} \mathrm{O}\right)$ menjadi gas hidrogen $\left(\mathrm{H}_{2}\right)$ dan oksigen $\left(\mathrm{O}_{2}\right)$. Pemisahan hidrogen $\left(\mathrm{H}_{2}\right)$ dan $\mathrm{O}_{2}$ dalam elektrolisis air.

Anoda ${ }^{(-)}$:

$$
\mathrm{H}_{2} \mathrm{O}(l) \rightarrow \frac{1}{2} \mathrm{O}_{2}(g)+2 \mathrm{H}^{+}+2 \mathrm{e}^{-}
$$

Katoda ${ }^{(+)}$:

$$
2 \mathrm{H}^{+}+2 \mathrm{e}^{-} \rightarrow \mathrm{H}_{2}(g)
$$

Reaksi penuh :

$$
\mathrm{H}_{2} \mathrm{O}(l) \rightarrow \mathrm{H}_{2}(g)+\frac{1}{2} \mathrm{O}_{2}(g)
$$

Dalam air murni pada katoda bermuatan negatif, reaksi reduksi terjadi, dengan elektron ( $\left.\mathrm{e}^{-}\right)$dari katoda diberikan ke kation hidrogen untuk membentuk gas hidrogen. Setengah reaksi, seimbang dengan asam dijabarkan dalam (Persamaan 7).

Reduksi pada katoda :

$$
2 \mathrm{H}^{+}(a q)+2 \mathrm{e}^{-} \rightarrow \mathrm{H}_{2}(g)
$$

Pada anoda bermuatan positif, terjadi reaksi oksidasi, menghasilkan gas oksigen dan memberikan elektron ke anoda untuk menghasilkan reaksi dijabarkan dalam (Persamaan 8).

Oksidasi pada anoda :

$$
2 \mathrm{H}_{2} \mathrm{O}(l) \rightarrow \mathrm{O}_{2}(g)+4 \mathrm{H}^{+}(a q)+4 \mathrm{e}^{-}
$$

\subsection{Kendali PID}

Dalam kontrol sistem dinamis, tidak ada controller yang menikmati keberhasilan dan kegagalan kontrol PID. Dari semua teknik desain kontrol, PID controller adalah yang paling banyak digunakan. Lebih dari $85 \%$ dari semua pengontrol dinamis adalah dari variasi PID. Berikut ini merupakan blok diagram dari sistem pengendali berumpan balik (closed loop) ditunjukkan pada Gambar 1. Dengan Set Point (SP) adalah suatu parameter nilai referensi atau nilai yang diinginkan. Present Value (PV) adalah variable terukur yang di umpan balikan oleh sensor. Keluaran pengendali PID akan mengubah respon mengikuti perubahan yang ada pada hasil pengukuran sensor dan set point yang ditentukan ditunjukkan pada persamaan.9. Pembuat dan pengembang pengendali PID menggunakan nama untuk mengidentifikasi ketiga model pada pengendali yaitu:

$$
\begin{array}{ll}
\mathrm{P}(\mathrm{Kp}) & =\text { Konstanta Proportional } \\
\mathrm{I}(\mathrm{Ki})=\int \frac{1}{\mathrm{~T}_{\mathrm{i}} \mathrm{S}}=\frac{\mathrm{K}_{\mathrm{i}}}{\mathrm{s}} & =\text { Konstanta Integral } \\
\mathrm{D}(\mathrm{Kd})=\mathrm{T}_{\mathrm{d}} \frac{\mathrm{e}(\mathrm{t})}{\mathrm{dt}} & =\text { Konstanta Derivative }
\end{array}
$$

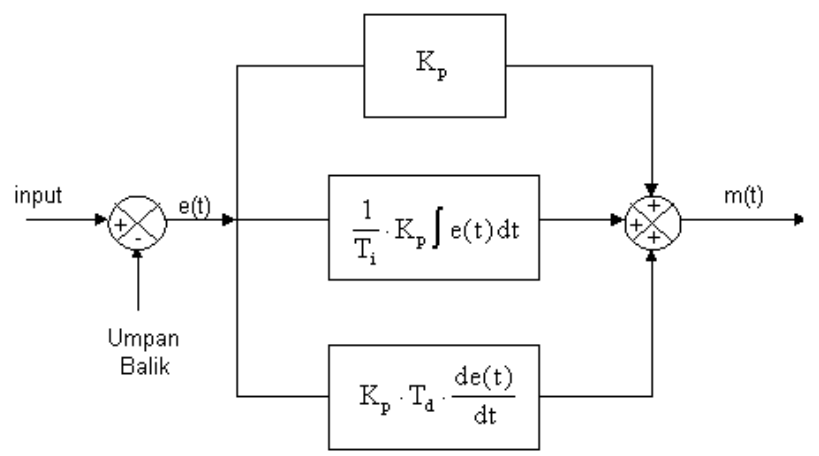

Gambar 1 Diagram Blok Sistem Pengendali Berumpan Balik

Atau secara umum persamaannya adalah sebagai berikut:

$$
u(t)=K_{p} \cdot e(t)+K i \cdot \int e(t) d t+K d \cdot \frac{d e(t)}{d t}
$$

\subsection{Model Sistem}

Reaktor hidrogen dengan pengaturan suplay sumber arus DC berbasis PID terdiri dari beberapa komponen utama yang ditunjukkan pada Gambar 2. 


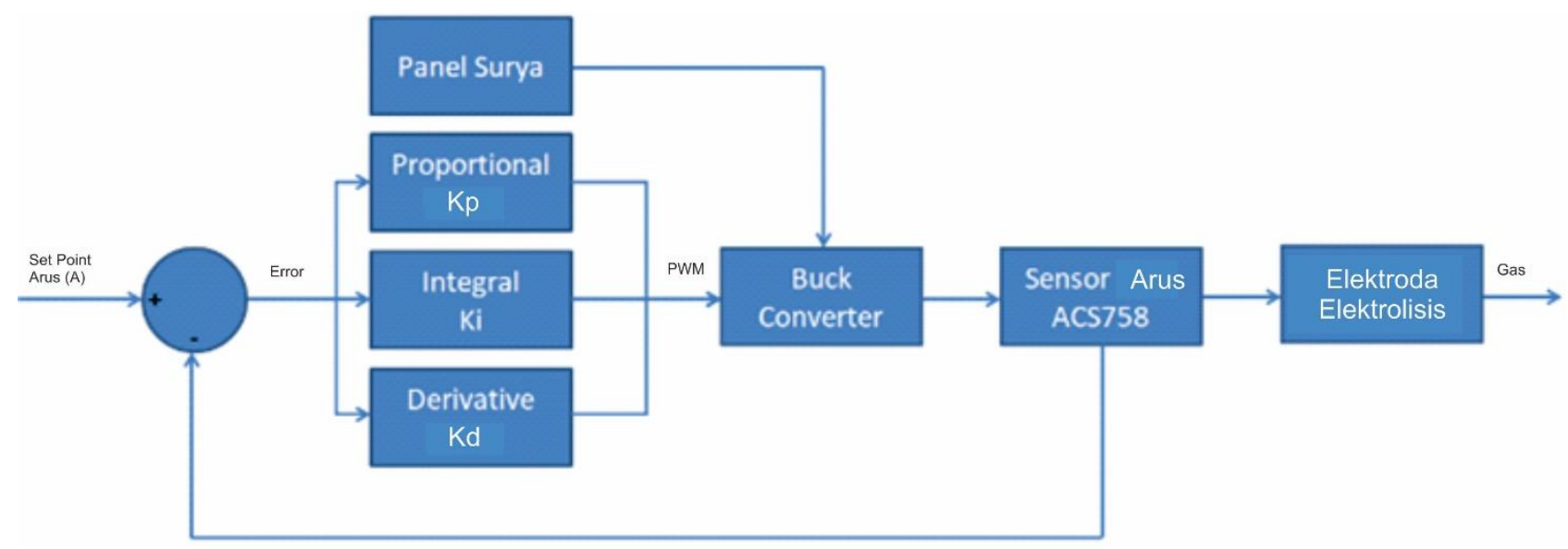

Gambar 2 Diagram Blok Sistem Keseluruhan

Panel Surya digunakan sebagai sumber pembangkit listrik DC yang dihasilkan dari radiasi cahaya matahari. Buck converter digunakan sebagai konverter sumber pembangkit lisrik dari Panel Surya menjadi sumber arus yang digunakan sebagai supply arus listrik DC reaktor (anoda dan katoda) dengan pengaturan PWM sebagai kontrol tegangan. Sensor arus digunakan sebagai pembaca besaranya arus yang mengalir ke reaktor. Mikrokontroller digunakan sebagai sistem embedded yang memproses besaran pembacaan arus listrik pada sensor, yang akan diproses dengan algoritma PID sebagai input parameter, sehingga kontrol dapat memproses output berupa PWM yang digunakan sebagai kontrol tegangan pada buck converter. Reaktor hidrogen merupakan beban utama dalam sistem ini, yang digunakan sebagai penghasil hidrogen dari proses elektrolisis air dengan spesifikasi elektoda ditunjukkan pada Tabel 1.

Tabel 1 Spesifikasi elektroda

\begin{tabular}{|l|l|}
\hline Bahan & Stainlesssteel \\
\hline Luas penampang & $\begin{array}{l}40 \times 20 \mathrm{~cm} \text { atau } 0,2 \times 0,1 \\
\text { meter }\end{array}$ \\
\hline Sisi penampang & 1 sisi \\
\hline Jumlah elektroda & $16(8$ katoda, 8 Anoda $)$ \\
\hline
\end{tabular}

\section{HASIL DAN PEMBAHASAN}

Tujuan dari pengujian ini adalah membandingkan efektfitas sistem elektrolisis menggunakan PID dan tanpa PID. Gambar 3 menunjukkan plat stainless steel yang digunakan sebagai elektroda elektrolisis, Gambar 4 menunjukkan tabung reactor elektolisis yang diisi menggunakan larutan elektrolit, Gambar 5 menunjukkan blok sistem kendali PID yang terdiri dari buck converter dan PID controller menggunakan Arduino Nano yang dapat dipantau menggunakan serial monitor pada PC. Neraca ukur digunakan sebagai parameter aliran gas $\mathrm{H}_{2}$ pada saat dilakukan elektrolisis.

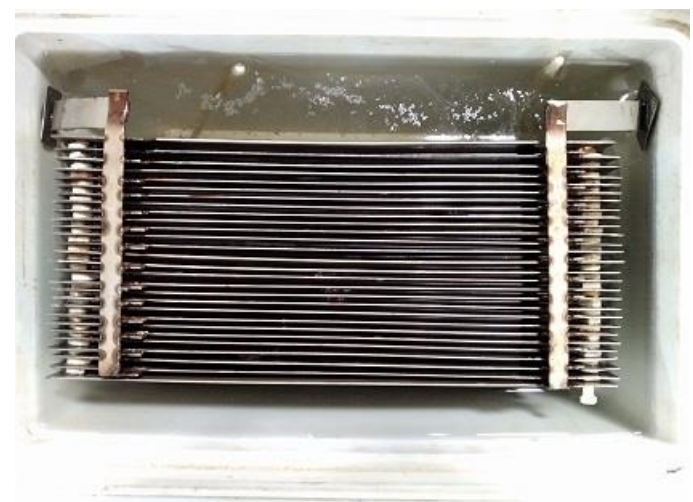

Gambar 3 Elektoda Stainless Steel

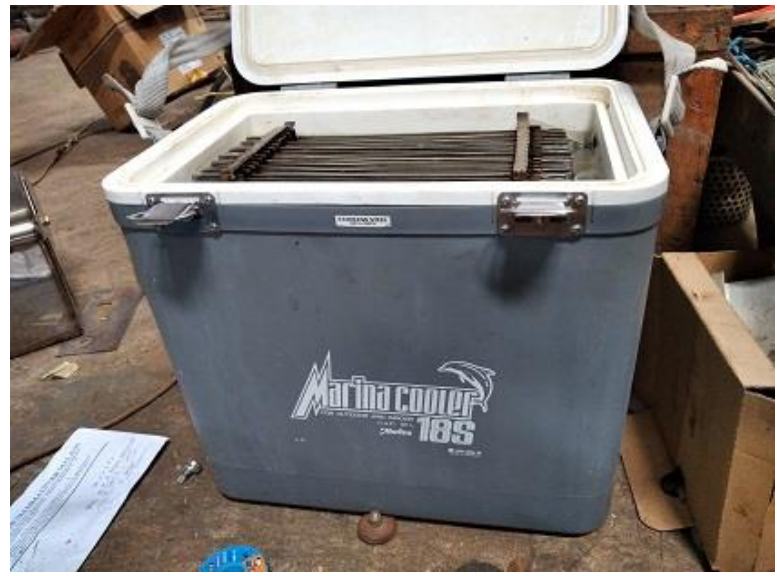

Gambar 4 Reaktor Hidrogen 


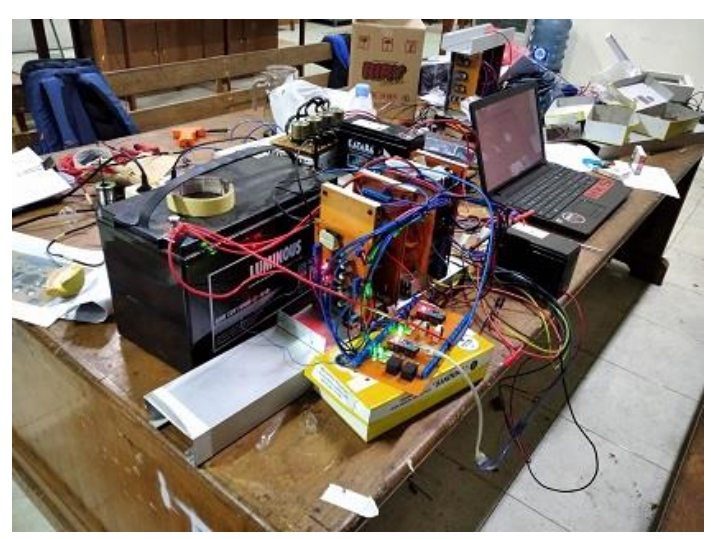

Gambar 5 Kontroler Elektolisis

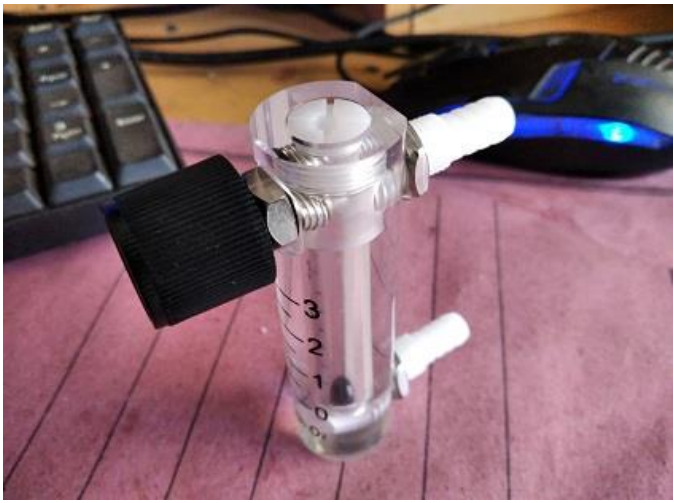

Gambar 6 Neraca Ukur

Tabel 2 Hasil Pengujian Elektrolisis

\begin{tabular}{|c|c|c|}
\hline \multirow{2}{*}{ No. } & \multicolumn{2}{|c|}{$\begin{array}{c}\text { Konsumsi Daya Poduksi } \\
\text { (WH) }\end{array}$} \\
& \multicolumn{2}{|c|}{ Per $\mathrm{m}^{3} \mathrm{H}_{2}$} \\
\cline { 2 - 3 } & PID & Tanpa PID \\
\hline 1 & 5,480 & 5,679 \\
\hline 2 & 5,598 & 5,779 \\
\hline 3 & 5,101 & 5,348 \\
\hline 4 & 5,300 & 5,678 \\
\hline 5 & 5,298 & 5,352 \\
\hline 6 & 5,680 & 5,766 \\
\hline 7 & 5,298 & 5,548 \\
\hline 8 & 5,444 & 5,750 \\
\hline 9 & 5,678 & 5,371 \\
\hline 10 & 5,120 & 5,664 \\
\hline $\mathrm{Rata}^{2} / \mathrm{m}^{3}$ & 5,400 & 5,594 \\
$\mathrm{H}_{2}$ & & \\
\hline
\end{tabular}

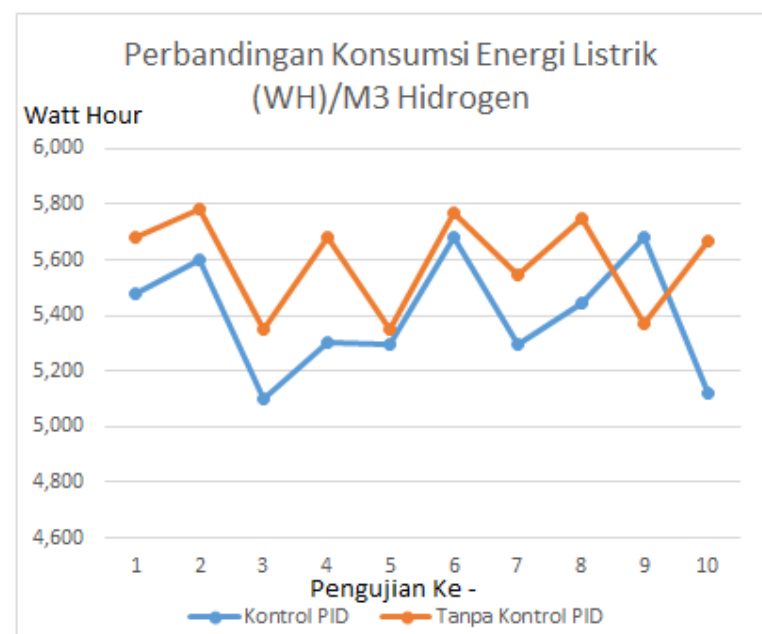

Gambar 7 Perbandingan konsumsi energi listrik per M3 $\mathrm{H}_{2}$

Berdasarkan hasil pengujian yang dilakukan dengan menggunakan kontrol PID dan tanpa menggunakan kontrol PID maka di dapatkan hasil bahwa dengan menggunakan kontrol PID dapat mengehmat konsumsi energi listrik. Ketika tidak menggunakan kontrol PID konsumsi energi listrik mencapai 5,594 per $\mathrm{m}^{3} \mathrm{H}_{2}$ sedangkan jika menggunakan kontrol PID maka dapat dilakukan penghematan sebesar 194 per $\mathrm{m}^{3} \mathrm{H}_{2}$ dengan energi listrik yang di konsumsi sebesar 5,400 per $\mathrm{m}^{3} \mathrm{H}_{2}$.

\section{KESIMPULAN}

Dari pengujian yang telah dilakukan terlihat bahwa konsumsi energi listrik pada produksi Hidrogen menggunakan elektrolisis air, menggunakan kendali PID memiliki efisiensi kinerja yag lebih baik, dengan rata-rata konsumsi daya sebesar 5400 Watt Hour atau sekitar 96,5\% konsumsi energy yang digunakan oleh sistem tanpa kendali PID yang mencapai 5594 Watt Hour.

\section{REFERENSI}

[1] K. Praveen and M. Sethumadhavan, "On the extension of XOR step construction for optimal contrast grey level visual cryptography," 2017 Int. Conf. Adv. Comput. Commun. Informatics, ICACCI 2017, vol. 2017-January, no. 8, pp. 219-222, 2017, doi: 10.1109/ICACCI.2017.8125843.

[2] C. R. P. Patel et al., "Enhanced hydrogen generation by water electrolysis employing carbon nano-structure composites," Int. J. 
Hydrogen Energy, vol. 43, no. 6, pp. 3180 3189, 2018, doi:

10.1016/j.ijhydene.2017.12.142.

[3] K. Mazloomi and C. Gomes, "Hydrogen as an energy carrier: Prospects and challenges," Renew. Sustain. Energy Rev., vol. 16, no. 5, pp. 3024-3033, 2012, doi: 10.1016/j.rser.2012.02.028.

[4] N. M. A. Y. Andewi and W. Hadi, "Sumber Energi Hydrogen Production By Electrolysis Process As an Energy," Jur. Tek. Lingkungan-FTSP-ITS, pp. 1-16.

[5] R. Rashid, I. Elamvazuthi, M. Begam, and M. Arrofiq, "Fuzzy-based Navigation and Control of a Non-Holonomic Mobile Robot," no. May 2014, 2010, [Online]. Available: http://arxiv.org/abs/1003.4081.

[6] A. M. Putra, "Analisis Produktifitas Gas Hidrogen Dan Gas Oksigen Pada Elektrolisis Larutan Koh," J. Neutrino, vol. 2, no. 2, pp. 141-154, 2012, doi: 10.18860/neu.v0i0.1642.

[7] R. P. I. Widarningtyas, Sulistyo, and Widayat, "Potential of Hydrogen Production through Alkaline Water Electrolysis Using Solar Radiation around Semarang," E3S Web Conf., vol. 125, no. 201 9, pp. 4-10, 2019, doi: 10.1051/e3sconf/201912510006.

[8] S. Yuliananda, G. Sarya, and R. R. Hastijanti, "Pengaruh perubahan intensitas matahari terhadap daya keluaran panel surya," $J$. Pengabdi. LPPM Untag Surabaya, vol. 01, no. 02, pp. 193-202, 2015.

[9] A. Pane, J., Surya, A., Novita, S., Mazmur, R., Aryza, A., Hamdani, Rizky, "Implementasi PID Dalam Mengendalikan Motor Menggunakan Metode PID dan Mikrokontroler Atmega," Sainteks 2019, no. Mv, pp. 196-201, 2019, [Online]. Available: https://seminarid.com/prosiding/index.php/sainteks/article/d ownload/155/153.

[10] S. Temel, S. Yagli, and S. Gören, "P , Pd , Pi , Pid Controllers," https://www.google.com.pr/url?sa $=t \& r c t=j \&$ $q=\& e s r c=s \&$ source $=w e b \& c d=1 \& c a d=r j a \&$ uact $=8$ \&ved $=$ OCBOQFjAAahUKEwig6ZPnyI $n J A h U G 5 C Y K H X 6 o B D I \& u r l=h t t p \% 3 A \% 2 F$ $\% 2 F w w w$.researchgate.net $\% 2 F f i l e$. PostFileL oader.html\%3Fid\%3D54685991d11b8bc966 8b461a\%26assetKey\%3DAS\%253A2736352 0017, p. 63, 2012.

[11] F. Arshad et al., "Controlled development of higher-dimensional nanostructured copper oxide thin films as binder free electrocatalysts for oxygen evolution reaction," Int. J. Hydrogen Energy, vol. 45, no. 33, pp. 16583-16590, 2020, doi: 10.1016/j.ijhydene.2020.04.152.

[12] M. R. Harahap, "Sel Elektrokimia: Karakteristik dan Aplikasi," CIRCUIT J. Ilm. Pendidik. Tek. Elektro, vol. 2, no. 1, pp. 177180, 2016, doi: 10.22373/crc.v2i1.764.

[13] R. A. Paz, "The Design of the PID Controller," Comput. Eng., 2001. 